\title{
DOES PERFORMANCE-BASED BUDGETING HAVE A CORRELATION WITH PERFORMANCE MEASUREMENT SYSTEM? EVIDENCE FROM LOCAL GOVERNMENT IN INDONESIA
}

\author{
Hafiez SOFYANI \\ Universitas Muhammadiyah Yogyakarta \\ Tamantirto, Kasihan, Bantul, Daerah Istimewa Yogyakarta, INDONESIA \\ e-mail: hafiez.sofyani@umy.ac.id
}

\begin{abstract}
This study aimed to empirically test some variables related to Performance-Based Budgeting (PBB) and Performance Measurement System (PMS) implementation in the local government, namely Special Region of Yogyakarta, Indonesia. This study applied the mixed-methods approach with sequential explanatory strategy (QUANTITATIVE to Qualitative). Quantitative stage was conducted by testing the hypothesis using the Structural Equation Model (SEM) approach. On the qualitative stage, the interview was conducted to dig more information on the unsupported hypothesis. From the result of the hypothesis testing, it was discovered that the limitation of information system had a negative influence, while education had a positive influence towards the effectiveness of PBB. Furthermore, the effectiveness of PBB had a positive influence towards budget absorption, and the accountability also had a positive influence towards the use of performance information to practice the arrangement of PPB. Meanwhile, the qualitative analysis produced the finding that there were practices of PBB that could still be done manually and it was not supported by information technology. Besides, the implementation of PMS and PBB was more because of the coercive pressure rather than consciousness of normative apparatus.
\end{abstract}

Keywords: local government, performance accountability, performance-based budgeting, Indonesia.

JEL: G38, H11, H61, H83.

\section{$1 \quad$ Introduction}

Indonesian government has been adopting the concept of New Public Management in the maintenance of organization, one of which was the PerformanceBased Budgeting (PBB) written implicitly within the Regulation of Minister of Domestic Affair (Permendagri) No. 13 of 2006 about the Guidance of the Maintenance of the Local Finance. Such a rule had experienced changes twice to become the Regulation of Minister of Domestic Affair (Permendagri) No 59 of 2007, and then, the Regulation of Minister of Domestic Affair (Permendagri) No 21 of 2011. The occurrence of the two changes indicate the presence of stages of process of finesses of the concept of local financial maintenance done by the Indonesian government. One of the aspects emphasized on the rule was that the Design of General Policy of Budgeting (Kebijakan Umum Anggaran/KUA) must be followed by the achievement of the targets of the performance formulated measurably. The objective was that to make the information written on the Public Policy Budgeting (RKA) local government and on the document of the RKA of the Organization of Local Officer (OPD) can be made as important information in implementing the control in realizing the budget.

Seen from the academic perspective, the development of PBB concept in the local government in Indonesia was actually based on the goal setting theory introduced by Locke and Brya (1969). This theory argued that to reach the maximum performance, the presence of clear formula between the target and the performance indicator output was needed. Such notion assured that the objective was defined clearly, and it would produce high level performance, assuming that there was some acceptance from the objectives set (Basri, 2013; Locke, 1975). However, in its practice, PBB entered within the rule of act that should have been implemented by all the local governments in Indonesia in order to maintain the finance that had not yet been able to carry them to achieve their best performance, grade "A". 
In 2016, the Ministry of State Apparatus Utilization and Reformation of Bureaucracy (MSAURB) assessed that in average, the performance of the local government in Indonesia was still C (www.men pan.go.id, 2017). From the report of the Ministry of State Apparatus Utilization and Reformation of Bureaucracy in 2016, out of the 34 local governments in the level of province (Pemprov), there were 16 Provincial Governments that received the title of CC and 1 was still D. Meanwhile, there were 15 Pemprovs that received good category (B and $\mathrm{BB}$ ) and only 2 Pemprovs obtained title A, which were the Special Region of Yogyakarta and East Java. Whereas, the PBB implementation had been running for more than a decade since 2007. The inability of NPM concept, where PPB to increase the performance of the province had become one practical gap, was very important to the study.

The studies related to the effectiveness of PBB implementation had been conducted several times within the context of the public sector in Indonesia (Wijayanti, et al., 2012; Kurrohman, 2013). However, some previous researches had focused on the analysis of PBB implementation (Wijayanti et al., 2012), the correlation between PBB and the performance of local government apparatus as well as the financial performance from the perspective of value for money (Kurrohman, 2013). Meanwhile, the study of PBB that connected to non-financial performance such as Performance Measurement System (PMS), specifically was the development system of performance measurement and the performance accountability (LAKIP) done by the researchers in this research was still very rare, or even had never been done especially on the context of research in Indonesia.

Besides, all the previous researches mentioned above only employed a single research approach: survey. It affected the argumentation described from the hypothesis which was not supported as it was only a prejudice. Therefore, the researchers made some sort of distinctive feature on this research by applying qualitative approach to find sufficiently strong argumentation in explaining the reasons why the hypothesis was not acceptable. Therefore, this study employed a mixed method with a sequential explanatory strategy, where the quantitative approach could be done at the early stage and then the result of the qualitative research was followed up by qualitative analysis (Cresswell, 2012).

This research was aimed to examine the correlation between the effectiveness of PBB implementation and some important variables such as limited information system, development of PMS, and education of the considered apparatus of the local government with budget absorption, performance accountability, and use of performance information in formulating the planning and budgeting for future. This research was conducted in the Local Government of Special Region of Yogyakarta (DIY) as having the "A" score, with the underlying reason that this research was expected to provide the description of empirical model that would be useful as an input for other local government, especially in an effort to reach better performance in the next periods.

\section{Literature review and the formulation of hypothesis}

\subsection{Performance-Based Budgeting (PBB)}

There are some definitions of the concept of Performance based Budgeting (PBB); referring to GA (1999), PBB was defined as the concept that connected information and budgeting. Technically, this concept is implemented by relating the funds allocated with the measurable results (OECD, 2005). Generally, PBB in government institution are aimed to improve the efficiency and effectiveness of the public procurement by connecting the funds from the government and the results achieved, and it was delivered to the public (Robinson, 2011). PBB itself was believed to be able to improve the quality of budget absorption, and it stimulated the use of performance information within each stage of budgeting (Ahyaruddin and Akbar, 2018).

Dealing with the practice of PBB in the local governments in Indonesia, the Indonesian Ministry of Finance (2009) explained 8 (eight) stages within the cycle of application of PBB, which are: 1) determining the strategic target; 2) determining the outcome, program, output and activities; 3 ) determining the main performance indicator program and the activity indicator program; 4) determining the standard of the cost; 5) the calculation of the need for 
budgeting; 6) the implementation activity and procurement; 7) accountability; and 8) the measurement and evaluation of the performance.

\subsection{Hypothesis Development}

Development of PMS showed the effort of the organization in developing it, which was reflected by determining the set of various types of output-oriented performance measurements for various policy / program / activities run by an organization (Cavalluzzo and Ittner, 2004). The development of performance measurement in local government was not only for implementing PMS, but also in arranging the working plan and budget. The implementation of development of good PMS would make the arrangement of the plan and budget also run well, because the performance indicator formulated would be easily understood and used in the formulation of PBB. According to Locke and Bryan (1969), the formula of performance indicator was prepared clearly as an institutional goal, and it would be able to help the institution in achieving the performance better. On the contrary, when the PMS was developed poorly, then the indicator to achieve the goal would hardly be translated and realized by the apparatus within the institution of the local government. This would then affect the ineffectiveness of implementation of PBB. Based on the explanation above, the hypothesis formulated was as follows:

\section{$\mathrm{H}_{1}$ : The development of performance measure-} ment system positively influences the effectiveness of performance-based budgeting

Information technology has been one of the important aspects for the organization in order to reach its goals (Jensen, 2007). Cavalluzzo and Ittner (2004) stated that one of the key factors that influenced the successful implementation of a policy related to the good governance and the performance on the organization was technology. These factors consist of new system compatibility with the existing system, complexity system, and the goodness of the new system compared to the existing system, for example, accuracy and timing.

Ali and Green (2009) found that a good maintenance of information system would be able to support the realization of implementation of a policy well; in this research context, it was the effectiveness of PBB in local government. It was also in line with what was expressed by Warland and Ridley (2005). This argumentation could be seen in reverse, when there were limitations of information system, it would then be the resistor of the effectiveness of the PBB implementation in the local government. This limitation presented in the form of the unavailability of the data for arranging the budget obtained, bad data validity, and incomplete data. Based on the explanation above, the hypothesis was formulated as follows:

\section{$\mathrm{H}_{2}$ : The limitations of information system nega- tively influences the effectiveness of performance- based budgeting.}

Riyanto and Utomo (2005) stated that in arranging an effective $\mathrm{PBB}$, it took relevant education, skill and experiences from the apparatus of the local government. In some local governments in Indonesia, the education especially related to the governance duties was created in order to be able to be a means to increase the performance of the local government. Madjid and Ashari (2013) stated that to increase the understanding of the employees in the Local government of Sleman, then the Board of Training and Development was formed. The objective was to make the local government be able to increase the quality of human resource of the employees within the environment of the local government, so that they were able to evaluate the absorption of the budget towards the consistency between planning and implementation, output as well as efficiency measurement. By the presence of education on budgeting, it was expected that the employees could arrange the budget for activities and programs based on the activities that would be conducted and were able to plan the term of budget realization, so that the process of budget absorption could be controlled and run effectively and efficiently. Based on the above explanation, the hypothesis was formulated as follows:

\section{$\mathrm{H}_{3}$ : Education has positive influence towards the effectiveness of implementation of perfor- mance-based budgeting}

Budget absorption was one of the indicators that can be used to measure the output performance and the 
efficiency from the formulation stage, planning and the budgeting on PBB mechanism (Kelly and Rivenbark, 2014). Furthermore, the budget absorption could be used as a controlling tool and the strategy to apply the budget in order to improve the performance of the government institution.

Habiburrochman and Rizki (2012) added that PBB had a characteristic as a sufficiently effective financial controlling tool since it was able to provide clear description on the specific goals of the organization that would be achieved within the budgeting target as well as to provide the qualified performance indicator. Therefore, the maintenance of the organization would always be able to assure the compatibility level of the actual procurement so that the realization of the procurement budget could be achieved as what has been planned.

Handoko and Ngumar (2014) revealed that the realization of the budget of the Department of City Income of Surabaya had become more efficient and effective thanks to the application of the PBB system in such institutions. Based on such a condition, the research hypothesis was formulated as follows:

\section{$\mathrm{H}_{4}$ : The effectiveness of performance-based budgeting positively influences the budget ab- sorption}

In the context of local government in Indonesia, a good absorption of the budget had become an indicator of an institution if it was titled as a good achiever or not. Pratolo and Jatmiko (2017) indicated that more working programs and services to the public were realized. Therefore, the assumption that emerged was the more the budget realized, the more people were served (Juliani and Sholihin, 2014). Since such high absorption of the budget was assessed as a good performance indicator, the phenomena occurring on field was that such high absorption of budget was made as a tool to look for sympathy of the public by the local government. Such phenomena was in gear with the perspective of the signaling theory (Connelly et al., 2011; Celani and Singh, 2011).

In the context of the local government, the good absorption of budget featured the institution's good performance was highly likely to be reported well because later, it would be delivered to the public in order to maintain the electability of the regional leader. With the report about such good budget absorption, the people would be satisfied and considered that the local government had been doing its job well, so that the people would maintain their votes over the leader of the region now for the future (Setiawan, 2016).

On the other side, the absorption of the budget either in the condition that matched with the target or not, would surely become an input for the local government. Input that was very much needed related to the absorption of the budget, which was about the reason why the budget absorption could either be low or high. For the local government, it was important to be studied in order to execute the continuous improvement in future period (Sofyani and Akbar, 2013). Based on those various arguments, the research hypothesis could be written as follow:

\section{$\mathrm{H}_{5 \mathrm{a}}$ : The absorption of the budget positively af- fected towards the performance accountability}

\section{$H_{5 b}$ : The absorption of the budget positively af- fected towards the use of performance indicator}

Some literature about the performance measurement mentioned that the availability of result-oriented performance information report would be able to increase the accountability of performance and the use of performance information to support the decision making in an organization (Sofyani and Akbar, 2013). This condition described the existence of the influence of performance accountability towards the use of performance information. The availability of performance information would make such information required in formulating the policy or decision making for the future budgeting period.

Kelly and Rivenbark (2014) stated that one of the factors that influenced the increase of the use of performance information was performance information (accountability) arranged by the organization. The increase of performance accountability would increase the will of the management and the staff to use the performance information in making the decision (see also: Sofyani and Akbar, 2013; Nurkhamid, 2008). Based on that, the hypotheses of the research were formulated as follows:

\section{$\mathrm{H}_{6}$ : The accountability of the performance posi- tively affected the use of performance information}




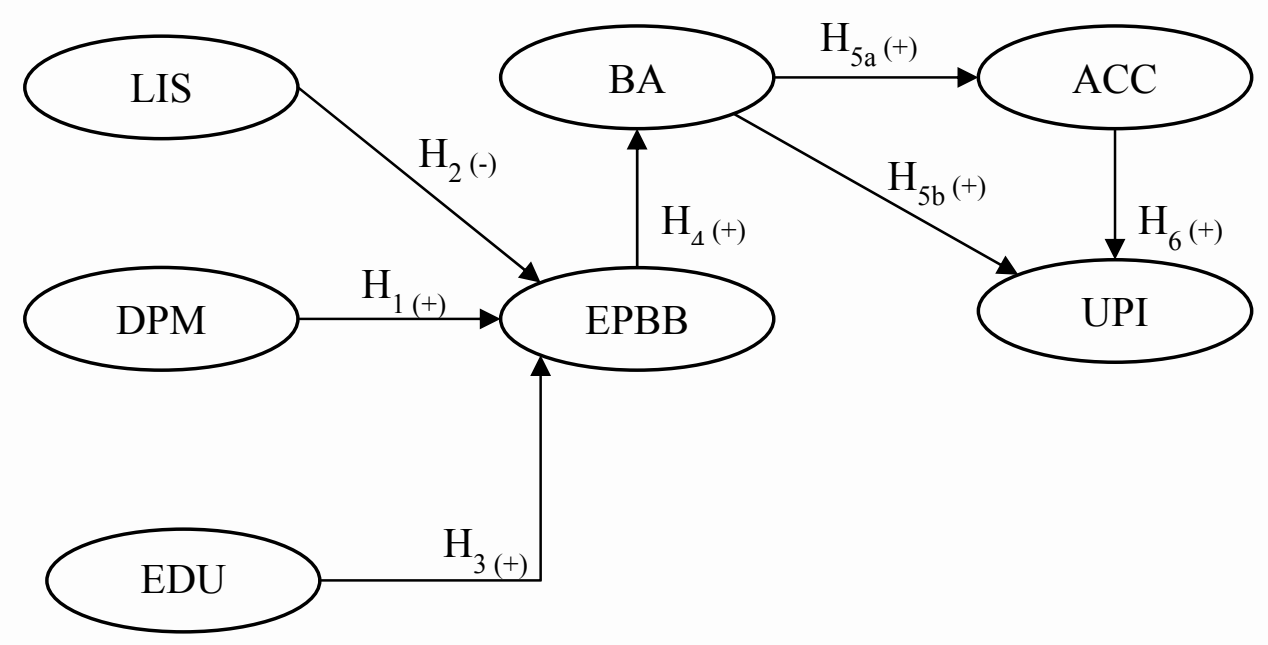

Figure 1. Research Model

From the formulated hypotheses research, then it could be described in the form of research model as presented in Fig. 1.

Note:

- Variables related to Performance Based Budgeting:

EPBB : The Effectiveness of PerformanceBased Budgeting

BA : Budget Absorption

LIS : Limitation of Information System

EDU : Education

- Variables related to Performance Measurement System:

DPM : The Development of Performance Measurement

ACC : Accountability

UPI : The Use of Performance Information

\section{$3 \quad$ Research method}

The research object was all the OPDs in the local government of Special Region of Yogyakarta (DIY). Determining the respondents used purposive sampling; respondents who represented the sample were chosen based on certain criteria; officials of the department/board/office involved within the process of planning, budgeting and performance reporting arrangement.

Therefore, the chosen respondents were believed to have understood the conditions within the depart- ment, office or board where he worked (Sofyani et al., 2018). Data collection technique was conducted by, first: delivering the questionnaire formulated by the researchers directly to all existing OPD in local government of DIY. Second, by interviewing the chosen respondent and two experts.

The variables of this research were: the Limitation of Information System (KSI), which was the limitation of information system ability possessed by an organization to provide the required valid, reliable, and punctual (Cavalluzzo and Ittner, 2004). Indicator from this variable was that the difficulty to obtain valid data, to obtain the data on time, to obtain the data completely, and the cost of data processing, which is expensive and timely inefficient (Cavalluzzo and Ittner, 2004).

The next limitation was the Development of Performance Measurement (DPM), which constituted the efforts of the organization in conducting the development of PMS reflected by determining the various types of result-oriented performance measurements for various policy/program/activities run by an organization. The instrument used to measure this variable was adopted from Cavaluzzo and Ittner (2004). These variable indicators were related to the development of performance indicator in OPD including the aspect of quantity, efficiency, service satisfactory and the quality service of working program.

Second, performance-based budgeting was a process of budget arrangement focusing on the benefit of the activities or the working program of the organiza- 
tion, where each activity or working programs must be able to measure the performance.

This variable was measured using the instrument developed by Achyani and Cahya (2011) using some indicators, which were: the effectiveness of PBB in repairing the program, the effectiveness of PBB in repairing the decision making, the effectiveness of PBB in coordinating the program implementation, the effectiveness in subtracting, poker overlapping, the effectiveness of PBB in its accountability, and the effectiveness of PBB in its performance evaluation.

Third, the Budget Absorption (PA) was translated as the level of realization of budget in the local government. This variable was measured by referring to the instruments developed by (Juliani and Sholihin, 2014) using the following indicators: priority scale planning, target planning, and priority scale realization, the obedience towards the rules and acts, and the comparison to the target last year.
Next was the Performance of Accountability (AKT) that was translated as the feeling of responsibility to reach the target of a program/activity/policy. These variable indicators were the program report, accountability initiative, and the evaluation coordination referred from the research (Cavalluzzo and Ittner, 2004).

The last variable was the Use of Performance Information (PIK), which was defined as various types of uses of performance information to support the decision making within an organization. This variable was also measured by referring to the instruments developed by Cavalluzzo and Ittner (2004). In the meantime, the indicators included: PIK to determine the priority of working program, PIK for allocating the human resource, PIK for program coordination, PIK to revise the performance indicator, and PIK for repairing the method of achieving performance.

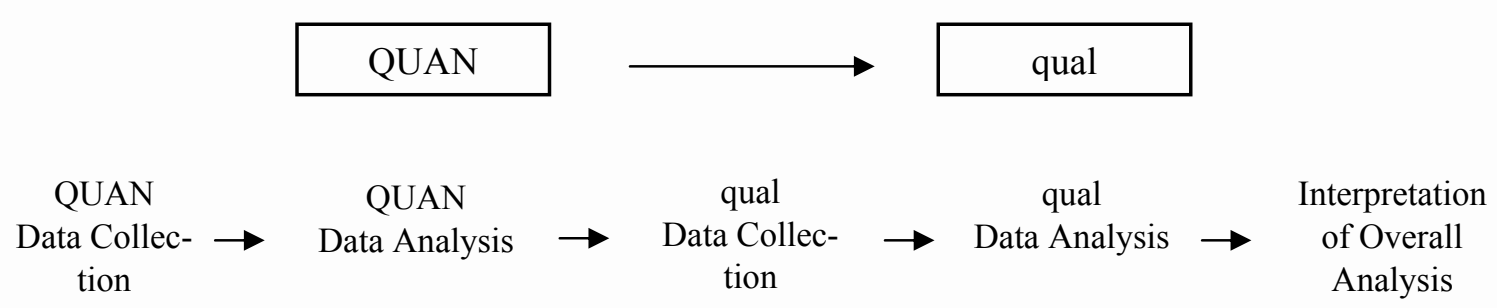

Figure 2. The Strategy of Sequential Explanatory

(Source: Creswell, 2012)

The data that was submitted in this research was the primary data through delivering questionnaires and interview to the respondents. The strategy applied was explanatory sequential (Creswell, 2012), by collecting and analyzing the quantitative data on the first stage and then followed by qualitative analysis and data collection (semi-structured interviewed) on the second stage, built based on the quantitative analysis (see Fig. 2). This method was used so that the research result, especially the unsupported explanation related to the hypothesis could be dug deeper. The main benefit from a mixed research is that it enables the researcher to propose confirmatory and exploratory questions. (Teddlie and Tashakkori, 2009).
The method of data analysis in the quantitative approach was using the Structural Equation Modeling (SEM) based on the variant (Hartono and Abdillah, 2011). This research used Partial Least Square to test the hypothesis, since the technique is very suitable for a research that aims to develop certain theory on a research with a relatively small sample and complicated model (Ghozali, 2008; Hartono and Abdillah, 2011; Sholihin and Ratmono, 2013).

For the qualitative approach, the interview technique used was conducting semi-structured and open interviews, which were recorded using an audio recorder, and then made the transcription out of it (Creswell, 2012). 
Data analysis was done by deductive thematic analysis approach (Braun and Clarke, 2006; Yaya, 2017). The steps taken including coding, grouping into categories, finding main ideas and grouping into themes, and then to find a general pattern from the tendency that managed to be discovered from the data.

To make sure about the reliability and the validity of the qualitative data collected, the researcher was required to execute some procedures, such as: to make sure of the data validity, he had to check the transcription result to make sure that no mistakes were made during the process of transcription. And then to make sure of the data reliability, it was required to answer some questions from his peers (peer-de-briefing) to increase the accuracy of the research result (Creswell, 2012).

\section{$4 \quad$ Result and discussion}

The collection of questionnaire data of this research took two weeks. It was made sure that there were no different answer by the respondents who received the questionnaire in the first week as compared to those who received in the second week, so that the last 80 responses (week two) compared to the previous 70 resposnses (week one), using the Mann Whitney Test (Field, 2009). From the result of the MannWhitney Test, it was discovered that all the answers of the early and the later respondents were not different statistically, based on Asymp. Sig. Score (2tailed), which was much higher than 0.05 . Therefore, it could be concluded that even though the data collection happened on slightly different periods, however, it did not affect the data homogeneity.

Respondent's profile is presented on Table 1. It can be seen that the respondents were dominated by bachelors and masters graduates. For the gender, it could be said that it was balanced, so that the result of this research did not find any trouble if it was connected to the gender issue.

Meanwhile, for the duration of serving on a position, it was dominant in $1-5$ years. It meant that regarding the duration of time served on a position, the experience of the respondent was categorized as new.

Table 1. Respondent's Profile

\begin{tabular}{|c|c|c|}
\hline Level of Education & Quantity & Percentage (\%) \\
\hline Diploma & 2 & 2.06 \\
\hline Bachelor & 49 & 50.52 \\
\hline Master & 44 & 45.36 \\
\hline Doctoral & 2 & 2.06 \\
\hline Total & 97 & 100.00 \\
\hline & Served duration (Year) & \\
\hline $1-5$ & 81 & 83.51 \\
\hline $5.1-10$ & 12 & 12.37 \\
\hline$>10$ & 4 & 4.12 \\
\hline Total & 97 & 100.00 \\
\hline & Gender & 46.39 \\
\hline Male & 45 & 53.61 \\
\hline Female & 52 & 100.00 \\
\hline Total & 97 & \\
\hline
\end{tabular}




\subsection{The result of quantitative approach}

Before the hypothesis test was carried out, the researcher tested the reliability and the validity (discriminant and convergent) from the survey data. The indicator of the fulfilled construct convergent validity could be seen on the outer loading, while discriminant validity was seen on the feature of discriminant validity. In addition, reliability construct was measured from the result of Cronbach Alpha calculation. From the result of the test of outer loading, it was found that indicator EPBB 3, ACC 1, ACC 4, LIS3, LIS 4, BA 4, BA 6, DPM 3, and
DPM 4 had score less than 0.7. Therefore, those indicators were eliminated and then the testing of reliability and validity was repeated. After the retest, it was discovered that the outer loading result, discriminant validity, and Cronbach alpha, each variable was more than 0.70 , except for accountability construct (ACC) for which the value of Cronbach alpha construct was less than 0.7 ; precisely, it was 0.666 (see Table 2). Since this number was very close to 0.70 , so such a construct was still considered to have a good quality of validity and reliability (Ringle et al., 2015).

Table 2. The Result of Instrument Quality

\begin{tabular}{|c|c|c|c|c|c|c|c|}
\hline \multicolumn{8}{|c|}{ Discriminant Validity } \\
\hline & EPBB & $\mathrm{ACC}$ & LIS & $\mathrm{BA}$ & UPI & DPM & EDU \\
\hline EPBB & 0.787 & & & & & & \\
\hline $\mathrm{ACC}$ & 0.127 & 0.689 & & & & & \\
\hline LIS & -0.125 & -0.235 & 0.724 & & & & \\
\hline BA & 0.020 & -0.079 & -0.151 & 0.729 & & & \\
\hline UPI & -0.094 & 0.475 & -0.062 & -0.219 & 0.815 & & \\
\hline DPM & 0.055 & 0.400 & -0.169 & -0.078 & 0.376 & 0.763 & \\
\hline EDU & 0.317 & 0.226 & 0.125 & 0.211 & 0.208 & 0.214 & 0.856 \\
\hline \multicolumn{8}{|c|}{ Convergent Validity } \\
\hline \multirow{10}{*}{ 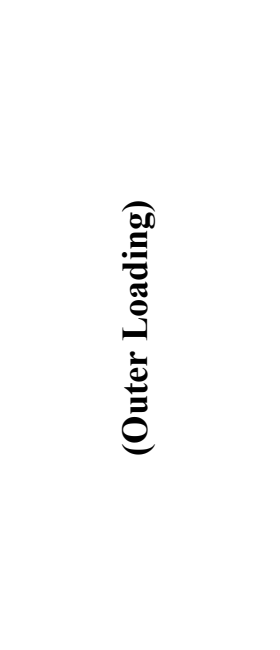 } & EPBB & $\mathrm{ACC}$ & LIS & BA & UPI & DPM & EDU \\
\hline & 0.701 & 0.853 & 0.923 & 0.801 & 0.833 & 0.960 & 0.797 \\
\hline & 0.782 & 0.877 & 0.931 & 0.825 & 0.839 & 0.832 & 0.935 \\
\hline & 0.785 & & & 0.868 & 0.802 & & 0.910 \\
\hline & 0.858 & & & 0.749 & 0.803 & & 0.748 \\
\hline & 0.725 & & & & 0.798 & & 0.873 \\
\hline & 0.881 & & & & & & \\
\hline & 0.902 & & & & & & \\
\hline & 0.745 & & & & & & \\
\hline & 0.791 & & & & & & \\
\hline \multicolumn{8}{|c|}{ Reliability } \\
\hline \multirow{2}{*}{ Cronbach Alpha } & EPBB & ACC & LIS & $\mathrm{BA}$ & UPI & DPM & EDU \\
\hline & 0.931 & 0.614 & 0.747 & 0.820 & 0.874 & 0.818 & 0.907 \\
\hline
\end{tabular}


The result of the research was divided into two parts, the first part explained the results of hypothesis that the test supported, and the in next part, the unsupported hypothesis reason based on the interview result with three respondents was explained.

Table 3 explains the summary of hypothesis testing result. It is noticeable that the limitation of information system negatively influenced PBB. The result was in gear with what had been explained by Ali and Green (2009) that the match of the information system with the function run would be able to support the organization to reach what had been taken care of well. On the contrary, the limited of information system would be able to resist the organization in implementing a certain policy, in this case was the PBB.

On Table 3, it could also be seen that the education of apparatus of local government brought positive influence towards PBB. The presence of education related to the performance-based budgeting empirically could support the effectiveness of PBB since the apparatus understood more and master the strate- gy that he used to have in the process of PBB (Madjid and Anshari, 2013). Furthermore, this research found that the PBB had a significant positive influence towards the budget absorption. It was in gear with what had been discovered by Handoko and Ngumar (2014) and Espinoza (2014).

This result was also in sync with what had been explained in the theory of goal determining that the presence of target of performance was formulated clearly on the process of PBB and it could be a controlling tool that would then support the institution in monitoring the budget absorption (Locke and Latham, 2013). Next, it was found that the accountability of the performance had a positive influence towards the use of performance information.

The result of this research was agreed with the findings of Cavalluzzo and Ittner (2004) and Sofyani and Akbar (2013). The presence of performance accountability gave the local government some material to evaluate the performance, and furthermore, it was used in formulating the planning and the budgeting for the next years.

Table 3. The Summary of Hypothesis Testing Result

\begin{tabular}{|c|c|c|c|c|c|}
\hline Hypothesis & Hypothesis Symbols & direction & Original Sample & t value & Conclusion \\
\hline $\mathrm{H}_{1}$ & $\mathrm{DPM} \rightarrow \mathrm{EPBB}$ & + & 0.014 & 0.115 & Not Supported \\
\hline $\mathrm{H}_{2}$ & $\mathrm{LIS} \rightarrow \mathrm{EPBB}$ & - & -0.199 & 2.263 & Supported \\
\hline $\mathrm{H}_{3}$ & $\mathrm{EDU} \rightarrow \mathrm{EPBB}$ & + & 0.174 & 2.575 & Supported \\
\hline $\mathrm{H}_{4}$ & $\mathrm{EPBB} \rightarrow \mathrm{BA}$ & + & 0.567 & 8.663 & Supported \\
\hline $\mathrm{H}_{5 \mathrm{a}}$ & $\mathrm{BA} \rightarrow \mathrm{ACC}$ & + & -0.039 & 0.454 & Not Supported \\
\hline $\mathrm{H}_{5 \mathrm{~b}}$ & $\mathrm{BA} \rightarrow \mathrm{UPI}$ & + & -0.235 & 2.819 & Not Supported \\
\hline $\mathrm{H}_{6}$ & $\mathrm{ACC} \rightarrow \mathrm{UPI}$ & + & 0.439 & 4.171 & Supported \\
\hline
\end{tabular}

\subsection{The Result of Qualitative Approach}

To find an explanation with adequate argumentation about the unsupported hypotheses, the researchers interviewed three informants. Two of them were Associate Professors from two reputed Universities in Indonesia and it had a deep concept towards the research within the local government board and had become the expert team for the guidance of maintenance and financial reporting on local government assigned by the Ministry of Domestic Affair of Republic of Indonesia. Meanwhile, one informant was from the Local government of Special Region of Yogyakarta. To make the reader at ease, the researcher presented the codification of the informant on Table 4. 
Table 4. Informant Codification

\begin{tabular}{|c|l|l|}
\hline Code & \multicolumn{1}{|c|}{ Level of Education } & \multicolumn{1}{c|}{ Experiences related to Local Government } \\
\hline SP & $\begin{array}{l}\text { Dr. of Public Sector Accounting in } \\
\text { Universitas Padjajaran }\end{array}$ & $\begin{array}{l}\text { - Expert staff in strengthening management and governance } \\
\text { quality of local government } \\
\text { - Financial Reporting Trainer of Government Institutions } \\
\text { at the Ministry of Home Affairs }\end{array}$ \\
\hline RA & $\begin{array}{l}\text { Ph.D. of Public Sector Accounting } \\
\text { in Curtin University }\end{array}$ & $\begin{array}{l}\text { - Expert staff in strengthening management and governance } \\
\text { quality of local government }\end{array}$ \\
\hline RW & $\begin{array}{l}\text { Master of Public Administration } \\
\text { Universitas Gadjah Mada }\end{array}$ & $\begin{array}{l}\text { - Head sub division of Local Government Employee Department } \\
\text { at the Ministry of Home Affairs }\end{array}$ \\
\hline
\end{tabular}

This research failed to support hypothesis 1 , or in other words, the limitation of the information system did not affect the correlation between the performance measurement development towards PBB. From the result of the interview with SP and RA, two similar conclusions of the unsupported $\mathrm{H}_{1}$ were found, which might be related to the finding on field about the interesting fact that the arrangement of information system of PBB and PMS was not integrated, yet it was done using a different software.

SP explained that the local government used to divide the job by forming special teams for different duties: budgeting team, PMS team and team for implementing budget. Finally, each team made their own performance indicator that was not integrated with one another. It almost happened everywhere in the local government in Indonesia. SP added that it should be enough for one local government to have one data storage and an integrated information system for implementing PMS and PBB. Therefore, the control of budget absorption and achievement of outcome of a program would be more comprehensive and not partial.

Another very interesting discovery for PMS implementation in some OPDs was that these were still executed manually using Microsoft Excel. Such a condition made it possible to make improvements of PMS statistically without being influenced by the PBB. From these findings, SP and RA strongly suggested that the local government should start to build an integrated information system and data storage of performance indicator, which can be used for the interest of PMS and PBB, so that it is possible to conduct performance target achievement on budget absorption and the outcome can be done comprehensively, continuously, in an interconnected manner and impartially. Given below is the interview result with RW and SP that became the findings of this research:

- "We use MS excel in the practice of arranging and reporting LAKIP. It is conducted by a special team." (Source: RW)

- "The fact is that in our local government (in Indonesia), often time the activity of PMS and PBB are conducted by different team[s] and they do not coordinate [with] each other. PMS team arrange their own formula of performance indicator and performance report for themselves, and PBB also arrange the performance target reports the performance of their budget by themselves, without any communication between the team[s]. Consequently, the achievement of the performance in the local government tends to be partial and not interconnected. It means that, when the performance was good, it does not mean that the outcome is good too". (Source: SP)

- "...this fact is correct and it has become our homework (Indonesia). It is very important for the local government in Indonesia to build an information system to support PMS and the most important is that they have to be integrated to the PBB. The local government must have a target data storage and performance indicator, and then, it will be the underlying for the imple- 
mentation of PMS and PBB. Therefore, the performance of local government from the aspect of budget absorption and outcome could go along well, inseparably." (Source: SP)

Furthermore, the unsupported $\mathrm{H}_{5 \mathrm{a}}$, maybe because in fact, PBB implementation was still dominant, was based on the isomorphism coercive. It was in gear with the research by Akbar et al., (2015) who found that the implementation of PBB policy was more because of the pressure from the Acts rather than its orientation to achieve vision and mission from the local government.

Consequently, PBB was only run partially and didn't have any synergy with PMS. Such a condition leads the local government to have more orientation on the output of performance report and had not been on the outcome of the target performance, so that the budget absorption did not connect with performance accountability. It could also be seen from the existence of the PIC on OPD which was separated from the party that took care of PMS and budgeting. Therefore, whether the budget absorption was running well or not, the employees were demanded to arrange the performance report.

Such a condition would probably explain the unsupported $\mathrm{H}_{5 \mathrm{~b}}$. From the interview result involving $\mathrm{RW}$ and RA, on the process of budgeting and planning for the coming year, the apparatus of local government were demanded to use information of the previous budget absorption presented in the report of performance. Such practice was conducted as a complimentary form of the Budget Working Plan, which is mandatory. This condition leads to the phenomena of procedural obedience (fake), not substantial on the process of budgeting in local government (Gudono, 2014). Given below is the interview result with RA:

- "In our department, those two things have their own caretaker[s]. For reporting the budget absorption, we always use it to evaluate. While for the use of performance information also the same." (Source: RW)

- "... Of course it has become the concern of the local government and he always asks and demands that the budget absorption and accountability reporting can be done right on time and based on the rule applied.... As employees, of course we have to do what has been the order of the leader. It is something normal and it has become our duty." (Source: RW)

- “... indeed in fact, on field, the implementation of PMS and PBB policy are dominated more by the pressure by the Act and the Ministry of Domestic affair. Because, it was a demand, therefore, regional apparatus government who see such policy as something that have to be done, willynilly he had to conduct it without seeing the essence of what actually they were doing. Eventually, if asked is the report of local government's performance is reported based on the date determined? Then the answer would be "Yes." But if we questioned if the performance report have been ideal and based on how it should be made? The answer would be "Not yet." This is the phenomena that happen in Indonesia." (Source: RA)

\section{Conclusion}

This research was aimed to test the correlation of the performance-based budgeting (PBB) variables with some other variables related to performance measurement system (PMS) in the Indonesian local government using mixed-method with explanatory sequential strategy. On the stage of quantitative approach, empirical evidence was found that the limitation of information system encountered by the local government made the effectiveness of the practice of PBB become less optimal.

The performance accountability of the good budget would lead to the local government to use the performance information on the process of arranging PBB in the next budgeting year. In addition, from qualitative stage, it was found that the not correlated development system of performance measurement towards the PBB was caused by the two policies that were run by the local government separately by forming special teams.

Meanwhile, the argument that might explain why budget absorption has no influence towards performance accountability is caused by the implementation of PMS and PBB strongly backed up by the pressure of the Act and the head of the region. 
The important implication from this research is that the local government should consider the update from the budget information system they have. The suitability of information system will be able to increase the performance of the local government and vice versa. Other very important implication is that the Ministry of Domestic Affair in Indonesia should build an integrated information system in implementing the policy of PBB and PMS. It needs to be done in order to reach the budget performance target to go along with the outcome performance achievement of a program.

Next, the practice of PBB should have run normatively, and not only as a pressure from the acts. This is required so that PBB is able to lead to the good and optimal budget absorption performance. Lastly, the local government was expected to have good accountability performance, since it will trigger the apparatus of the local government to use information on the performance report to become an input of information in arranging PBB in the next year period. Therefore, the continuity of achievement of the goal of the local government written on the budgeting was highly expected, either in short or long term, it could be achieved consistently.

This research has some limitations; first is that this research was only done in the Special region of Yogyakarta, so that the result can be generalized nationally. Moreover, in foreign countries, recalling the characteristics of the government in several states is very different.

Further research can be done in other local governments and replicated or developed in other developing countries. Further research is suggested to use other approaches, such as exploratory sequential or sequential, so that there would be more new research results that would benefit the development of management practices and good governance in government institutions.

\section{References}

[1] Achyani, F., Cahya, B.T., 2011. Analysis of Rational Aspects in Public Budgeting on the Effectiveness of Performance-Based Budgeting Implementation at Government of Surakarta. MAKSIMUM, 1(2), pp.68-77.
[2] Ahyaruddin, M., Akbar, R., 2017. Indonesian Local Government's Accountability and Performance: The Isomorphism Institutional Perspective. Journal of Accounting and Investment, 19(1), pp.1-11.

[3] Akbar, R., Pilcher, R. A., and Perrin, B., 2015. Implementing performance measurement systems: Indonesian local government under pressure. Qualitative Research in Accounting and Management, 12(1), pp.3-33.

[4] Ali, S., Green, P., 2009. IT governance mechanisms in public sector organizations: An Australian context. Handbook of Research on Information Management and the Global Landscape, pp.458-478.

[5] Basri, Y.M., 2013. Conflict Mediation Roles and Procedural Justice in Relationship Measurement Performance With Managerial Performance. Jurnal Akuntansi dan Keuangan Indonesia, 10(2), pp.225-242.

[6] Braun, V., Clarke, V., 2006. Using Thematic Analysis in Psychology. Qualitative Research in Psychology, 3, pp.77-101.

[7] Cavalluzzo, K.S., Ittner, C.D., 2004. Implementing performance measurement innovations: evidence from government. Accounting, Organizations and Society, 29(3), pp.243-267.

[8] Celani, A., Singh, P., 2011. Signaling theory and applicant attraction outcomes. Personnel review, 40(2), pp.222-238.

[9] Connelly, B.L., Certo, S.T., Ireland, R.D., and Reutzel, C.R., 2011. Signaling theory: A review and assessment. Journal of Management, 37(1), pp.39-67.

[10] Creswell, J.W., 2012. Research Design: Qualitative, Quantitative and Mixed Methods Approaches. California: Sage Publication.

[11] Departemen Keuangan Republik Indonesia, and Kementerian Negara Perencanaan Pembangunan Nasional/Badan Perencanaan Pembangunan Nasional. 2009. Pedoman Penera-pan Penganggaran Berbasis Kinerja (PBK) (2 ed.). Jakarta: Departemen Keuangan Republik Indonesia.

[12] Field, A., 2009. Discovering statistics using SPSS: SAGE Publications.

[13] GAO, 1999. Performance Budgeting: Initial Experiences Under the Results Act in Linking 
Plans With Budgets GAO/AIMD/GGD-99-67. Washington, D.C: General Accounting Office.

[14] Ghozali, I., 2008. Structural Equation Modeling: Alternative Metode with Partial Least Square (PLS). Semarang: Badan Penerbit Universitas Diponegoro.

[15] Gudono, 2014. Institutional Theory. Yogyakarta: BPFE Yogyakarta

[16] Habiburrochman, and Rizki, A., 2012. Effect of Performance-Based Budgeting to Effectiveness of Control: (A Study Case at Indonesia's State University). In: World Business Research Conference, Bangkok, Thailand, $6^{\text {th }}$ October 2012. Bangkok: Publication International Social Science, pp.121-130.

[17] Handoko, A.W., and Ngumar, S., 2014. Analysis of Realization of Revenue and ExpenditureBased Budgeting in Revenue Department of Surabaya. Jurnal Ilmu and Riset Akuntansi, 3(12), pp.1-16.

[18] Hartono, J., Abdillah, W., 2011. Concept and Application of PLS (Partial Least Square) for Empirical Research. Yogyakarta: BPFE Yogyakarta.

[19] Jensen, R., 2007. The digital provide: Information (technology), market performance, and welfare in the South Indian fisheries sector. The quarterly Journal of Economics, 122(3), pp.879924.

[20] Juliani, D., Sholihin, M., 2014. The influence of contextual factors on the perceptions of budget absorption related to procurement of goods/services. Jurnal Akuntansi dan Keuangan Indonesia, 11(2), pp.177-199.

[21] Kelly, J.M., Rivenbark, W.C., 2014. Performance budgeting for state and local government. New York: Routledge.

[22] Locke, E.A. 1975. Personnel attitudes and motivation. Annual review of psychology, 26(1), pp.457-480.

[23] Locke, E.A., Bryan, J.F., 1969. The directing function of goals in task performance. Organizational Behavior and Human Performance, 4(1), pp.35-42.

[24] Locke, E.A., Latham, G.P., 2013. New developments in goal setting and task performance: New York: Routledge.
[25] Madjid, N.C., Ashari, H., 2013. Analisis Implementasi Anggaran Berbasis Kinerja (Studi Kasus pada Badan Pendidikan dan Pelatihan Keuangan). Jakarta: Badan Pemeriksa Keuangan.

[26] Nurkhamid, M., 2008. Innovation of Performance Measurement System Implementation on Government Institutions. Jurnal Akuntansi Pemerintah, 3(1), pp.45-76.

[27] OECD., 2005. Modernising Government: The Way Forward. Paris: OECD Publishing.

[28] Pratolo, S., Jatmiko, B., 2017. Management Accounting for Local Government. Yogyakarta: LP3M UMY.

[29] Ringle, C.M., Wende, S., Becker, J.-M., 2015. SmartPLS 3. Boenningstedt: SmartPLS GmbH, http://www. smartpls. com. [Accessed 22 August 2017].

[30] Riyanto, A., Utomo, W., 2005. PerformanceBased budgeting Implementation in Sleman Regency. Sosiosains, 19(1), pp.205-2017.

[31] Yaya, R., 2017. Twelve years of Scottish school public private partnerships: Are they better value for money? Journal of Public Procurement, 17(2), pp.187-228.

[32] Robinson, M., 2011. CLEAR Training Materials: Performance-based Budgeting (Manual). Johannesburg: Regional Centers for Learning on Evaluation and Results.

[33] Setiawan, L., 2016. Implikasi Kebijakan Politik Ekonomi Partai Terhadap Tingkat Elektabilitas Partai Dalam Pemilu (Studi Kasus Pada 5 Pemilihan Umum Legislatif di Indonesia Dari Tahun 1997 Sd 2014). POLITIKA: Jurnal Ilmu Politik, 7(1), pp.115-137.

[34] Sholihin, M., Ratmono, D., 2013. SEM-PLS Analysis with WarpPLS 3.0 for Nonlinear Correlation in Social and Business Research. Yogyakarta: ANDI Publishing.

[35] Sofyani, H., Akbar, R., 2013. Relationship of Internal Factors Institution and Implementation of Government Institution Accountability System in Local Government. Jurnal Akuntansi dan Keuangan Indonesia, 10(2), pp.207-235.

[36] Sofyani, H., Akbar, R., Ferrer, R.C., 2018. 20 Years of Performance Measurement System (PMS) Implementation in Indonesian Local 
Governments: Why is Their Performance Still Poor?. Asian Journal of Business and Accounting, 11(1), pp.151-227.

[37] Teddlie, C., Tashakkori, A., 2009. Foundations of mixed methods research: Integrating quantitative and qualitative approaches in the social and behavioral sciences. New York: Sage Publication.

[38] Warland, C., Ridley, G., 2005. Awareness of IT control frameworks in an Australian state government: A qualitative case study. In: System Sciences, 2005. HICSS'05. Proceedings of the 38th Annual Hawaii International Conference,
Hawaii, USA, $6^{\text {th }}$ January 2005. Hawaii: IEEE Explore, pp.236b-236b.

[39] Wijaya, A.H.C., Akbar, R., 2013. The Influence of Information, Organizational Objectives and Targets, and External Pressure towards the Adoption of Performance Measurement System in Public Sector. Journal of Indonesian Economy and Business: JIEB., 28(1), pp.62-73.

[40] Wijayanti, A.W., Muluk, M.R.K., and Nurpratiwi, R., 2012. Performance-Based Budget Planning in Pasuruan Regency. WACANA, Jurnal Sosial dan Humaniora, 15(3), pp.10-17. 